\title{
Sugar Beet Yield and Quality As Affected by Growth Regulators, Mineral and Bio-Fertilization in Nubaria Region
}

\author{
Gomaa, M.Abd El-aziz., Essam.E. Kandil and, Hassan.Y.I. Yousif
}

\begin{abstract}
Two field experiments were carried out at Nubaria Region during 2017/2018 and 2018/2019 seasons, to study the effect of mineral, biofertilizer and growth regulators on sugar beet plant var Kowemira. Two field experiments were conducted at a split plot design in three replications, where the main plots were assigned to growth regulators (water, Gibberellin, Kainten, Indole acetic acid=IAA), while the mineral and biofertilizer treatments were distributed at random with the sub plots i.e., $(100 \%$ mineral-N (T1), 75\% mineral- $\mathrm{N}+$ Cerealine(T2), $75 \%$ mineral $\mathbf{N}+$ Nitrobine(T3), $50 \%$ mineral $\mathbf{N}+$ Cerealine + Nitrobine (T4)). The results showed that there was significant effect of growth regulators, combination mineral and biofertilizer and their interaction. The results demonstrated that using growth regulators (IAA or Kainten) as foliar application with combination with $\mathbf{5 0 \%}$ mineral fertilizer and biofertilizers (Cerealine and Nitrobine) or $\mathbf{7 5 \%}$ mineral fertilizer with biofertilizer (Nitrobine) achieved the highest yield, yield components and quality of sugar beet crop.
\end{abstract}

Keywords: Sugar beet, growth regulators, mineral, biofertilizer, yield.

\section{INTRODUCTION}

The importance of sugar beet crop to agriculture is not confined only to sugar production, but also it is adapted to saline, sodic and calcareous soils. It may be coming in the same importance as main source of sugar production with sugar cane in Egypt. About $40 \%$ of the world sugar production is obtained from sugar beet. Mineral, biofertilizer and growth regulators are considered as main factors affecting sugar production from sugar beet. Improving sugar beet yield and quality are the main goals of the Egyptian governmental policy to enhance sugar production in order to gradually cover the gap between sugar consumption and production by sowing the suitable variety under suitable conditions (FAO 2018).

Growth regulators regulate growth under normal or stress conditions, indole acetic acid (IAA) plays a main role in maintaining plant growth under stress conditions including salt stress. Growth regulators in sugar beet are used to improve biological values of seed and growth regulation and development of the vegetation to increase the yield of roots and their sugar content. The

DOI: 10.21608/asejaiqjsae.2019.46963

${ }^{1}$ Plant Production Department, The Faculty of Agriculture (Saba Basha), Alexandria University

Received July 28, 2019, Accepted August 27, 2019 possibilities of impact of intensive formation of new leaves in spring period or deposition of reserve substances into root in autumn, increase of sugar content and sugar production were examined. Regulation of the process of creation of white sugar yield is very difficult. Double treatment with the growth regulators Atonik or Rastim $30 \mathrm{DKV}$ increases root yield/ha by 3 to $5 \%$ and that it does not affect significantly the sugar content of sugar beet yield should be added by the fact that in yielding. The rate of respiration was reduced after treated sugar beet by the growth regulator. Its improved sugar production and it decreases storage losses of sugar before its technological processing by lower respiration during storage. Foliar application of IAA $(15 \mathrm{mg} / \mathrm{l})$ considerably ameliorated the adverse effects of salt on these plants (Gulnaz et al., 1999, Synkova et al. 2004, Ashraf, 2009, Egamberdieva, 2009, Guru Devi et al., 2012 and Tognetti et al., 2012).

Sugar beet root yield was increased due to seed inoculation treatments with biofertilizers over control treatment. Other yield and yield components were also increased especially by biofertilization. While, increases in yield and yield components were lower than or comparable to mineral fertilizer application. Finally, they showed that microbial inoculation of seeds with Bacillus polymyxa and Bacillus megaterium var. phosphaticum, alone or in dual combinations, may substitute costly NP fertilizers in sugar beet production (Cakmakci et al., 1999). Inoculation of sugar beet seeds with Azotobacterin significantly increased root length and diameter, TSS $\%$, sucrose $\%$, and root yield as well as sugar yield/fed. Also, Ramadan et al. (2003) revealed that biofertilization treatments had significant effect on root length, root diameter, root yield, top yield and sugar yield/fed. On the other wise, biofertilization treatments exhibited insignificant effect in sucrose and purity percentages (Sultan et al., 1999).

Biofertilizers are microbial inoculants used for application to either seeds for increasing soil fertility with aim of increasing the number of such microorganisms and to accelerate certain microbial processes. Such microbiological processes can change unavailable forms of nutrients into available ones that can be easily assimilated by plants (Subba, 2001). Seed inoculation of 
sugar beet with Cerealine or Phosphorine or both significantly affected root yield (Nemeat Alla, 2004). Biofertilizers recorded the highest root weight and diameter (Abou-Atteia and Abdelaal, 2007, Alaa et al. (2009) and Amin et al., 2013).

Bio-fertilizers are low cost, effective and renewable source of plant nutrients to supplement chemical or mineral fertilizers (Boraste et al., 2009). Biofertilizers are useful substitutes to inorganic fertilizers which improve soil quality and it is a natural product carrying living microorganisms derived from the root or cultivated soil (Attarde et al., 2012). Application of biofertilizer $+50 \%$ of the recommended dose $\mathrm{N}$ led to significant increase in diameter of the main stem, thickness of epidermis, cortex, secondary xylem, secondary phloem and pith diameter of flax plants. Anatomical studies of sugar beet root showed that biofertilizers increased the thickness of growth rings of sugar beet roots and average diameter of xylem vessels (Agamy et al., 2013).

Inoculation seeds of sugar beet with bio-fertilizer + $60 \mathrm{~kg} \mathrm{~N} /$ ha produced the highest mean values of root weight/plant and per hectare compared with fertilizing plants with $100 \mathrm{~kg} \mathrm{~N} / \mathrm{ha}$ alone (Favilli et al., 1993).Yield and quality of sugar beet increased with fertilizing with $100 \mathrm{~kg} \mathrm{~N} /$ fed inoculated with mixture of bio-fertilizer and sprayed with macronutrients (Amin et al., 2013). Also, Abdelaal and Tawfik (2015) cleared the significant increase in root length, and root diameter as well as root yield/fed in treated sugar beet with combination of bio-fertilizers and $105 \mathrm{~kg}$ mineral $\mathrm{N}$. However, Abdelaal (2015) pointed out that the combined treatments of Cerealine with $75 \%$ of the recommended dose of $\mathrm{N}$ and phosphorine, and cerealine with $50 \%$ of the recommended dose of $\mathrm{N}$ showed the highest values of root length and diameter, shoot and root fresh weights, TSS, and sucrose percentage as well as root and sugar yield/fed in both growing seasons in comparison with using each treatment alone as well as $100 \%$ mineral N. However, the highest values of sucrose $\%$ was resulted from treatment of phosphorine, and cerealine with adding $50 \% \mathrm{~N}$.

The aim of this investigation is to study the effect of biofertilizer and growth regulators on sugar beet production under Nubaria region conditions.

\section{MATERIALS AND METHODS:}

Two field experiments were carried out at Nubaria region, Egypt during 2017/2018 and 2018/2019 seasons, to study the effect of mineral and biofertilizer besides growth regulators on sugar beet (Beta vulgaris L. var Kowemira) under Nubaria region.

The preceding summer crop was maize (Zea mays L.) in both seasons. Before planting, soil samples were randomly taken from the experimental site at a depth of 0 to $30 \mathrm{~cm}$ from soil surface and prepared for chemical analysis according to method described by Chapman and Pratt (1978) as shown in Table (1).

Table 1. Some physical and chemical properties of the experimental soil sites.

\begin{tabular}{|c|c|c|}
\hline \multicolumn{3}{|c|}{ Season } \\
\hline Soil properties & $2017 / 2018$ & 2018/2019 \\
\hline A-Mechanical & 19.0 & 18.0 \\
\hline Clay \% & 24.5 & 24.2 \\
\hline Silts \% & 56.5 & 57.8 \\
\hline Sands & & \\
\hline Texture soil & \multicolumn{2}{|c|}{ Sandy loam } \\
\hline \multicolumn{3}{|l|}{ B- Chemical analysis clay loam soil } \\
\hline $\mathrm{pH}$ & 8.1 & 8.3 \\
\hline $\operatorname{Ec}(\mathrm{ds} / \mathrm{m})$ & 2.9 & 1.8 \\
\hline \multicolumn{3}{|l|}{ Anions (meq/l) } \\
\hline $\mathrm{HCo}_{3}^{-}$ & 1.8 & 2.2 \\
\hline $\mathrm{Cl}^{-}$ & 24.6 & 25.0 \\
\hline $\mathrm{So}_{4}^{--}$ & 1.7 & 2.0 \\
\hline \multicolumn{3}{|l|}{ Cations (meq/l) } \\
\hline $\mathrm{Cu}^{++}(\mathrm{meg} / \mathrm{l})$ & 5.0 & 4.9 \\
\hline $\mathrm{Mg}^{++}(\mathrm{meg} / \mathrm{l})$ & 6.2 & 5.9 \\
\hline $\mathrm{Na}^{++}(\mathrm{meg} / \mathrm{l})$ & 13.6 & 12.4 \\
\hline $\mathrm{K}^{+}(\mathrm{meg} / \mathrm{l})$ & 1.5 & 1.6 \\
\hline Available nitrogen (ppm) & 70.0 & 68.5 \\
\hline $\mathrm{K}(\mathrm{ppm})$ & 5.50 & 5.8 \\
\hline Organic matter $(\%)$ & 0.45 & 0.27 \\
\hline
\end{tabular}


The soil of field experiments was prepared through two ploughing and leveling. Weeds were three times manually controlled by hand hoeing at three times. Common agricultural practices for growing sugar beet plant according to the recommendations of Ministry of Agriculture and land Reclamaintion were followed, except the factors under study.

Seeds of sugar beet variety Kowemira were obtained from Sugar Crop Research Institute, Agricultural Research Center, Giza. Seeds were hand sown as the usual dry sowing on one side of the ridge in hills $25 \mathrm{~cm}$ apart at the rate of $4-5$ seed balls per hill on $9^{\text {th }}$ and $12^{\text {th }}$ October in the two successive seasons and harvested after 6 months.

The experimental design was split plot design in three replications, experimental unit was $10.5 \mathrm{~m}^{2}$, included 5 ridges, $60 \mathrm{~cm}$ apart and $3.5 \mathrm{~m}$ long, $(1 / 400$ fed, fed $=4200 \mathrm{~m}^{2}$ ). The main plots were occupied by growth regulators [water, Gibberellin $\left(\mathrm{GA}_{3}\right)$, Kainten (K), Indole acetic acid (IAA)] at the rate of $300 \mathrm{mg} / \mathrm{l}$, while the sub plots were occupied by mineral and biofertilizer i.e. (100\% mineral-N, $75 \%$ mineral- $\mathrm{N}+$ Cerealine, $75 \%$ mineral $\mathrm{N}+$ Nitrobine, $50 \%$ mineral $\mathrm{N}$ + Cerealine + Nitrobine) .

The treatments of $\mathrm{N}$ were $100 \%, 75 \%$ and $50 \%$ of the recommended dose of $\mathrm{N}$, where $100 \% \mathrm{~N}(150 \mathrm{~kg}$ urea), $75 \% \mathrm{~N}$ (112.5 kg urea) and 50\% N (75 kg urea) as urea $(46.5 \% \mathrm{~N})$, the amount of urea for each treatment was divided into two equal doses, the first application was done after thinning and the second one was carried out after 30 days from the first one.

Cerealine and Nitrobine as commercial products were obtained from Bio-fertilizer Unit, Agricultural Research Center (ARC), Giza, Egypt. Cerealine and Nitrobine is a free-living nitrogen-fixing bacterium, represents the best characterized genus of plant growthpromoting rhizobacteria. Sugar beet seeds inoculated with Cerealine and Nitrobine at rates of $400 \mathrm{~g} / \mathrm{fed}$ for each. Before the inoculation, Arabic gum was used as an adhesive agent of bio-fertilizers to sugar beet seeds and then directly sown.

Mono calcium superphosphate $\left(15.5 \% \mathrm{P}_{2} \mathrm{O}_{5}\right)$ at the rate of $100 \mathrm{~kg}$ and potassium sulphate $\left(48 \% \mathrm{~K}_{2} \mathrm{O}\right)$ at the rate of $50 \mathrm{~kg} \mathrm{~K}_{2} \mathrm{O} / \mathrm{fed}$. The whole amount of calcium superphosphate was added before sowing during soil preparation, while potassium sulphate was added with the first dose of urea.

Plant fresh weight $(\mathrm{g})$, root weight $(\mathrm{g})$, root length $(\mathrm{g})$, root diameter $(\mathrm{cm})$, biological yield $(\mathrm{t} / \mathrm{fed})$, root yield ( $\mathrm{t} / \mathrm{fed})$, top yield $(\mathrm{t} / \mathrm{fed})$, sugar yield $(\mathrm{t} / \mathrm{fed})$, TSS (\%) as well as sucrose (\%) were studied. Where, TSS and sucrose percentage estimated in fresh samples of sugar beet root by using Saccharometer according to the method described by A.O.A.C. (1995).

All obtained data were statistically analyzed according to the technique of analysis of variance (ANOVA) for the split plot design as published by Gomez and Gomez (1984). Least Significant Difference (LSD) method was used to test the differences between treatment means at $5 \%$ level of probability. Correlations of the traits obtained from the experiment were computed using Costat program. All the statistical analyses were performed using CoStat V 6.4 (2005) for Windows.

\section{RESULTS AND DISCUSSIONS}

Results in Table (2) showed the effect of growth regulators, $\mathrm{N}$ - mineral- biofertilizer and their interaction on plant fresh weight $(\mathrm{g})$, root weight $(\mathrm{g}) / \mathrm{plant}$, root length $(\mathrm{cm})$, root diameter and biological yield $(\mathrm{t} / \mathrm{fed})$ during 2017/2018 and 2018/2019 seasons.

In regarding to effect of the growth regulators, the results in the same Table revealed that foliar application of indole acetic acid (IAA) recorded the highest mean values of plant weight $(\mathrm{g})$, root weight $(\mathrm{g}) /$ plant, root length $(\mathrm{cm})$, root diameter and biological yield $(\mathrm{t} / \mathrm{fed})$ followed by foliar application of Kainten then gibberellin as compared with control (water) which recorded the lowest ones in both seasons. This increase in these traits may be due to the vital role of IAA or Kainten in growth and yield of plant. These results are in the same line with those recorded by Ashraf (2009), Egamberdieva (2009), Guru Devi et al. (2012) and Tognetti et al. (2012).

Results in the same Table, also showed the significant effect of mineral- biofertilizer $(\mathrm{N})$ where the highest mean values of plant weight (g), root weight (g), root length $(\mathrm{cm})$, root diameter and biological yield (t/fed) with fertilizing sugar beet plants by $50 \%$ mineral $\mathrm{N}$ fertilizer + biofertilizer (Cerealine + Nitrobine) in both seasons. Meanwhile, $100 \%$ mineral fertilizer $\mathrm{N}$ or $75 \%$ mineral $\mathrm{N}+$ Cerealine gave the lowest ones in both seasons. Meanwhile, the highest mean value of plant weight obtained under the application of $\mathrm{T} 2$ and $\mathrm{T} 4$ treatments where the mean values of plant weight under those treatments were not great enough to reach the $5 \%$ of significant as shown in Table (2). The increases of these traits could be due to role of combination of mineral and biofertilizer for crops and soil. These findings are in harmony with those obtained by Agamy et al. (2013), Amin et al. (2013), Abdelaal (2015), Abdelaal and Tawfik (2015). Biofertilizer use have emphasized that dual or combined inoculation showed 
higher productivity than single inoculation (Rajendran and Devaraj, 2004 and Shah et al., 2006).

Results in the that Table, again cleared that the interaction between growth regulators and combined of mineral fertilizer with biofertilizer $(\mathrm{N})$ resulted a significant effect on plant weight $(\mathrm{g})$, root weight $(\mathrm{g}) /$ plant, root length $(\mathrm{cm})$, root diameter and biological yield $(\mathrm{t} / \mathrm{fed})$ in the first and the second seasons. This showed that growth regulators and combined of mineral fertilizer with biofertilizer $(\mathrm{N})$ act dependently on the previous mentioned characters.

With regard the interaction effect, the results in Table (2) showed that the interaction between growth regulators and combined of mineral fertilizer with biofertilizer $(\mathrm{N})$ resulted a significant effect on plant attributes of sugar yield in the first and second seasons.

Table 2. Plant attributes of sugar beet as affected by growth regulators and mineral $\mathbf{N}$, biofertilizer and their interaction in both seasons.

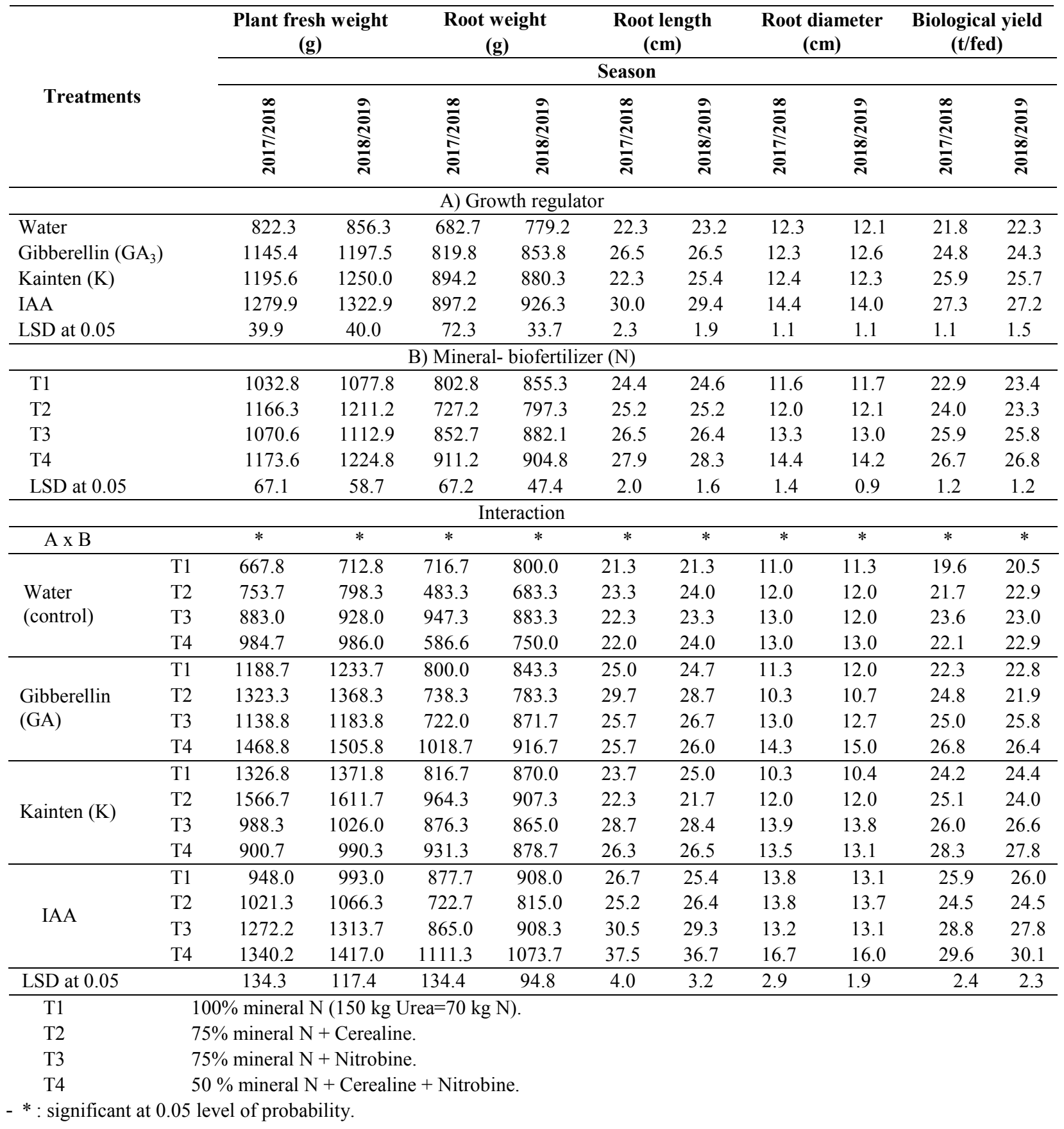


Where, foliar application of IAA or Kainten (K) with application of combined $50 \%$ mineral fertilizer $(\mathrm{N})$ and inoculation seed by $\mathrm{T} 4$ (Cerealine and Nitrobine) achieved the highest value of these traits except plant weight with $\mathrm{T} 2$ which gave the highest ones in both seasons of this our study.
The obtained results in Table (3) showed the effect of foliar application of growth regulators, $\mathrm{N}$ - mineral + biofertilizer and their interaction on root yield $(\mathrm{t} / \mathrm{fed})$, top yield ( $\mathrm{t} / \mathrm{fed})$, sugar yield ( $\mathrm{t} / \mathrm{fed})$, total soluble solid (TSS\%) and sucrose (\%) during 2017/2018 and 2018/2019 seasons.

Table 3. Plant attributes of sugar beet as affected by growth regulators and mineral $\mathbf{N}$, biofertilizer and their interaction in both seasons.

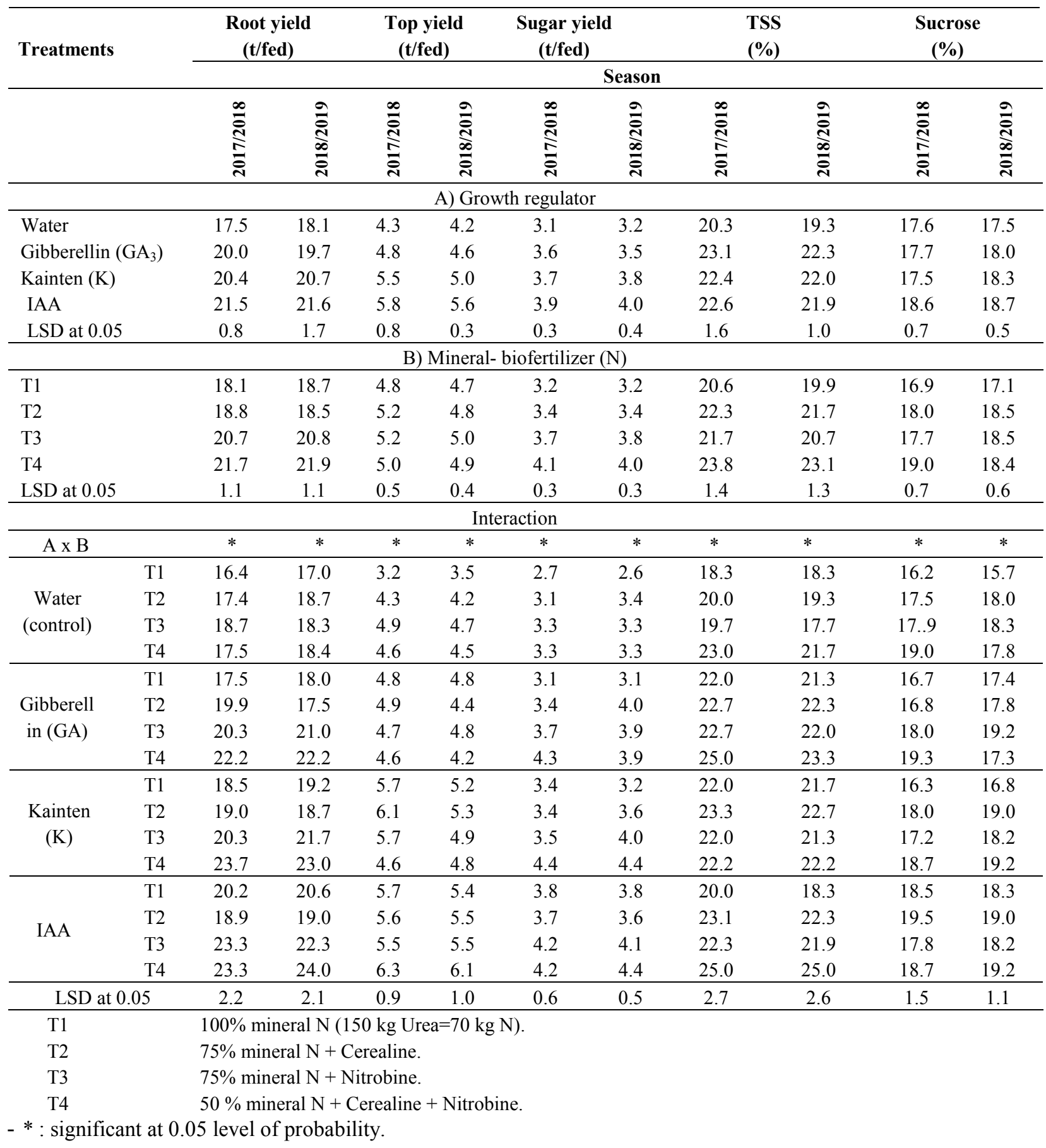


In respect to foliar application of growth regulators effect, the results revealed that foliar application of indole acetic acid (IAA) achieved the highest mean values of root yield (21.5 and $21.6 \mathrm{t} / \mathrm{fed})$, top yield (5.8 and $5.6 \mathrm{t} / \mathrm{fed}$ ), sugar yield (3.9 and $4.0 \mathrm{t} / \mathrm{fed})$, total soluble solid (TSS\%) (22.6 and $21.9 \%)$ and sucrose (18.6 and $18.7 \%$ ) followed by foliar application of Kainten then gibberellin as compared with control (water) which gave the lowest ones in both seasons. This increase in these traits may be due to the vital role of IAA or Kainten or gibberellin for crop yield. These results are in the same line with those results were recorded by Ashraf (2009), Egamberdieva (2009), Guru Devi et al. (2012) and Tognetti et al. (2012).

The results in the same Table cleared the significant effect of combination of mineral $\mathrm{N}$ fertilizer and biofertilizer $(\mathrm{N})$, where fertilizing sugar beet plants by $50 \%$ mineral $\mathrm{N}$ fertilizer + biofertilizer (Cerealine + Nitrobine) recorded the highest mean values of root yield (21.7 and $21.9 \mathrm{t} /$ fed), top yield (5.0 and $4.9 \mathrm{t} / \mathrm{fed})$, sugar yield (4.1 and $4.0 \mathrm{t} / \mathrm{fed})$, total soluble solid (TSS) (23.8 and $23.1 \%$ ) and sucrose (19.0 and $18.4 \%)$ followed by application of combination of $75 \%$ mineral fertilizer with Nitrobine in both seasons. Meanwhile, $100 \%$ mineral fertilizer $\mathrm{N}$ recorded the lowest ones in both seasons. The increases of these traits could be due to the role of combination of mineral and biofertilizer for crops and soil. These findings are in harmony with those obtained by Agamy et al. (2013), Amin et al. (2013), Abdelaal (2015), Abdelaal and Tawfik (2015). However, Cakmakci et al. (2001) confirmed that Cerealine caused an increase in $\mathrm{TSS} \%$, sucrose $\%$ and sugar yield/fed. Biofertilizer use have emphasized that dual or combined inoculation showed higher productivity than single inoculation (Rajendran and Devaraj, 2004 and Shah et al., 2006).

Cerealine and Nitrobine are bio-fertilizers which contain one or more of the previous N- fixing bacteria. They are known for fixing atmospheric nitrogen and benefit host plants by supplying growth hormones and vitamins. Biofertilizers play a crucial role in the reduction of in organic fertilizers and its utilization. There has been considerable progress during the recent past in the development of biofertilizers production technology and has been established to some extent as an efficient tool for increasing the trees and plants yield. (Jamaluddin, 2002).

With regard the interaction effect, the results in Table (3) showed that the interaction between growth regulators and combined of mineral fertilizer with biofertilizer $(\mathrm{N})$ resulted a significant effect on yield and its component of sugar yield in the first and second seasons. Where, foliar application of IAA or Kainten (K) with application of combined 50\% mineral fertilizer (N) and inoculation seed by biofertilizer (Cerealine and Nitrobine) achieved the highest value of root yield $(\mathrm{t} / \mathrm{fed})$, top yield $(\mathrm{t} / \mathrm{fed})$, sugar yield $(\mathrm{t} / \mathrm{fed})$, total soluble solid (TSS\%) and sucrose (\%) in both seasons of this our study.

\section{CONCLUSION}

The results of this investigation revealed that the foliar application of growth regulators (IAA or Kainten) with combination between $50 \%$ mineral fertilizer and biofertilizers (Cerealine and Nitrobine) or $75 \%$ mineral fertilizer with biofertilizer (Nitrobine) to achieve the highest yield, yield components and quality of sugar beet crop variety Komera at Nubaria region.

\section{REFERENCES}

A.O.A.C. 1995. Association of Official Analytical Chemists. Official methods of analysis, $16^{\text {th }}$ edition, AOAC International, Washington, DC.

Abdelaal, K.A. A. 2015. Pivotal role of bio and mineral fertilizer combinations on morphological, anatomical and yield characters of sugar beet plant (Beta vulgaris L.). Middle East J. Agric. Res. 4(4): 717-734.

Abdelaal, K. A. A. and S. F. Tawfik. 2015. Response of sugar beet plant (Beta vulgaris L.) to mineral nitrogen fertilization and bio-Fertilizers, Int. J. Curr. Microbiol. App. Sci. 4(9):677-688.

Abou-Atteia, F.A.M. and K. A. A. Abdelaal. 2007. Effect of bio and mineral fertilization on the main insect pests and some characters of sugar beet plants, J. Agric. Sci. Mansoura Univ., Egypt. 32(2): 1471-1485.

Agamy, R., M. Hashem, and S. Alamri (2013). Effect of soil amendment with yeasts as bio-fertilizers on the growth and productivity of sugar beet. African J. Agric. Res. $8(1): 46-56$.

Alaa, I.B., N.M.M. Awad and M. I. Sahar 2009. Productivity and quality of sugar beet as affected by rates of potassium and some micronutrients under two locations. Minufiya J.Agric.Res. 34(6):2131-2144.

Amin, G.A., E.A. Badr and M.H.M. Afifi. 2013. Root yield and quality of sugar beet (Beta vulgaris L.) in response to biofertilizer and foliar application with micronutrients. World Appl. Sci. J. 27(11):1385-1389.

Ashraf, M. 2009. Biotechnological approach of improving plant salt tolerance using antioxidants as markers. Biotech Adv. 27: 84-93.

Attarde, S. B., S. D. Narkhede, R. P. Patil and S. T. Ingle. 2012. Effect of organic and inorganic fertilizers on the growth and nutrient content of Abelmoschus esculentus L. (okra crop). Int. J. Current Res. 4(10):137-140. 
Boraste, A., K.K. Vamsi, A. Jhadav, Y. Khairnar, N. Gupta, S. Trivedi, P. Patil, G. Gupta, M. Gupta, A.K. Mujapara and B. Joshi. 2009. Bio-fertilizers: A novel tool for agriculture. Int. J. Microbial. Res. 1(2):23- 31.

Cakmakci, R., F. Kantar and F. Sahin. 2001. Effect of N2 fixing bacterial inoculation on yield of sugar beet and barley. J. Plant Nutrition and Soil Sci. 164(5): 527-531.

Cakmakci, R., F. Kantar and O.F. Algur. 1999. Sugar beet and barley yields in relation to Bacillus polymyxa and Bacillus megaterium var. phosphati inoculation. J. Plant Nut. and Soil Sci. 162 (4): 437-442.

Chapman, H.D. and R.F. Pratt. 1978. Methods analysis for soil, plant and water. Univ. of California Div. Agric. Sci. 16-38.

CoStat, Ver. 6.4. 2005. Cohort software798 light house Ave. PMB320, Monterey, CA93940, and USA. email: info@cohort.com and Website: http://www.cohort.com/DownloadCoStatPart2.html

Egamberdieva, D. 2009. Alleviation of salt stress by plant growth regulators and IAA producing bacteria in wheat. Acta Physiol Plant. 31: 861-864

FAO, 2018. Food Agric. Organization. www.fao.org/faostat/en/\#data.

Favilli, F., R. Pastorelli, and A. Gori. 1993. Response of sugar beet to Azospirillum bacterization in field experiments. Agric. Mediterr. 123:281-285.

Gomez, K. A. and A. A. Gomez. 1984. Statistical Procedures for Agricultural Research. $2^{\text {nd }}$ ed. John willey and Sons Inc. New York.

Gulnaz, A., J. Iqbal, S. Farooq and F. Azam. 1999. Seed treatment with growth regulators and crop productivity. I. 2,4-D as an inducer of salinity-tolerance in wheat (Triticum aestivum L.). Plant Soil. 210: 209-217.

Guru Devi, R., V. Pandiyarajan and P. Gurusaravanan. 2012. Alleviating effect of IAA on salt stressed Phaseolus mungo (L.) with reference to growth and biochemical characteristics. Rec. Res. Sci. Tech. 4: 22-24.
Jamaluddin, A. 2002. Bioinoculants for sustainable forestry. Bioinoculants for Sustainable agriculture and forestry: Proceedings of National Symposium Held on February. 16-18:21-25.

Nemeat Alla, E . A .E . H. 2004 Effect of some agronomic practices on yield and quality of sugar beet. M .SC. thesis, Fac . Agric ., Kafr EL-sheikh ,Tanta Univ., Egypt.

Rajendran, K. and P. Devaraj. 2004. Biomass and nutrient distribution and their return of Casuarina equisetifolia inoculated with biofertilizers in farm land. Biomass and Bioenergy. 26(3): 235-249.

Ramadan, B.S.H., H.R. Hassan and Fatma, A. A. 2003. Mineral and biofertilizers effect on photosynthetic pigments, root quality, yield components and anatomical structure of sugar beet (Beta vulgaris L.) plants grown under reclaimed soils. J. Agric. Sci. Mansoura Univ. 28(7): 5139-5160.

Shah, S. K., R. P. Shah, H. L. Xu and U. K. Aryal. 2006. Biofertilizers: an alternative source of nutrients for sustainable production of tree crops. J. Sustainable Agric. 29(2): 85-95.

Subba, R. N. S. 2001. Soil Microbiology Science. Publishers, Inc., Enfield, New Hampshire, USA. 407 p.

Sultan, M.S., A.N. Attia, A.M. Salama, A.E. Sharief and E.H. Selim. 1999. Biological and mineral fertilization of sugar beet under weed control: I- Sugar beet productivity. Proc. $1^{\text {st }}$ Intern. Conf. on Sugar and Integrated .Industries "Present \& Future", 15-18 ${ }^{\text {th }}$ Feb. 1999, Luxor, Egypt. I: 170-181.

Synkova, H., S. Semoradova and L. Burketova. 2004. High content of endogenous cytokinins stimulates activity of enzymes and proteins involved in stress response in Nicotiana tabacum. Plant Cell Tissue Organ. Cult. 79: 169-179.

Tognetti, V.B., P.E.R. Müllenbock and F. Van Breusegem. 2012. Stress homeostasis the redox and auxin perspective. Plant Cell Environ. 35: 321-333. 


\section{الملخص العربي}

\section{إنتاجية وجودة بنجر السكر تأثراً بمنظمات النمو والتسميد الكيماوي والحيوي في منطقة النوبارية} محمود عبد العزيز جمعة، عصام إسماعيل قنديل، حسن يوسف ابر اهيم يوسف

متوسطات قيم للصفات مقارنة بالرش بالجبرلين ومعاملـــة المقارنة (الرش بالماء) خلال موسمى الدراسة.

كما وجد هناك تــأثير اً معنويــاً لمعــاملات التـسميد الكيماوي و الحيوي غلى صفات المحصول وجودته لبنجر

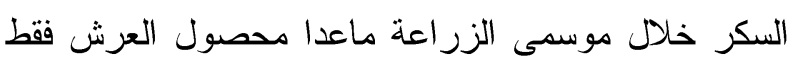

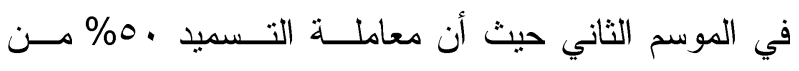

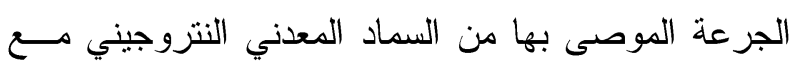
تلقيح البذور بالسريالين و النتروبين أعطت أعلـى صــــات للمحصول ومكوناته خلال موسمى الدراسة تليها معاملــــة

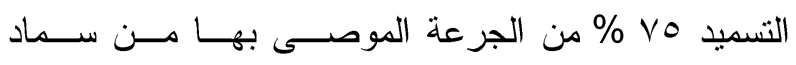
النتروجيني المعدني مع التلقيح البكتيري بالسماد الحيــوي النتروبين خلال موسمي الدر اسة.

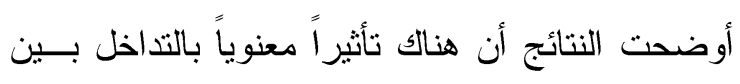

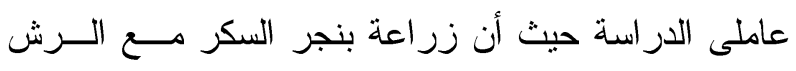

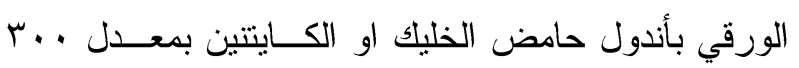

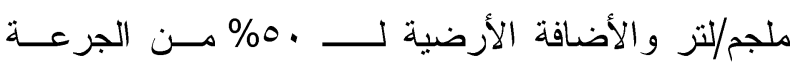
الموصى بها من السماد المعدني النتروجيني وتلقيح البذور

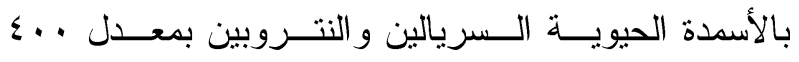

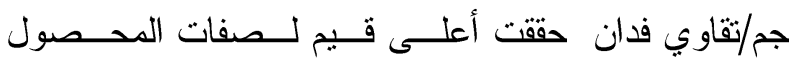
و الجودة تحت ظروف منطقة النوباريــة خــلال موســمي الدر اسة.

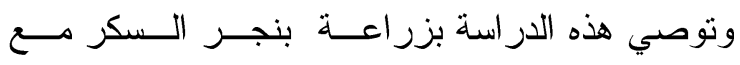
استخدام الرش الورقي بمنظمات النمو منل الكايتين و اندول

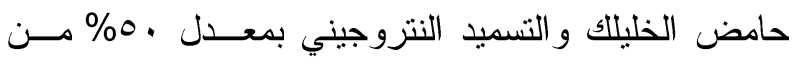
الجرعة الموصى بها مع التـسميد الحيـوي بالــسريالين

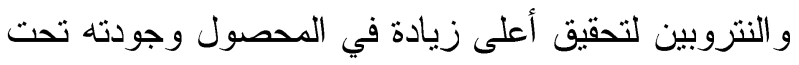
ظروف منطقة النوبارية.
أجريت هذه الدر اســـة بطريــق مــصر - الأســكندرية

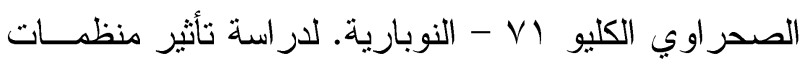

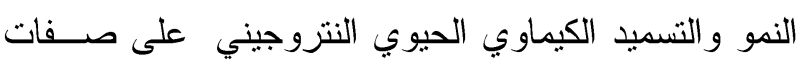
المحصول و الجودة لصنف بنجر السكر (كــو اميرا) خــلال

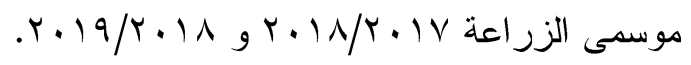
تم تتفيذ التجارب في التصميم التجريبي القطع المنـشقة مرة و احدة ووزعت المعاملات كالتالي: 1- منظمات النمو (ماء وحض الجبـــلين والكـــاينتين

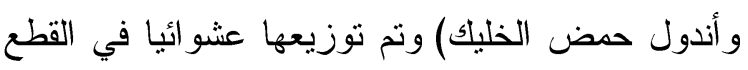

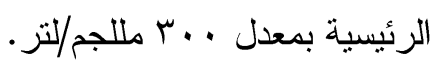

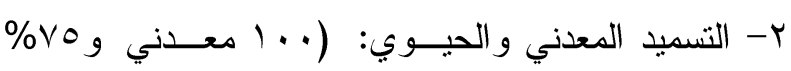

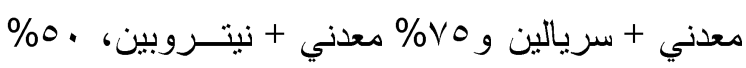
معدني + نريالين + نيتزوبين ) وتم توزيعها عـشو ائيا في القطع الفرعية. وكان ميعاد الزراعة في 9، با اكتوبر خلال موسمي

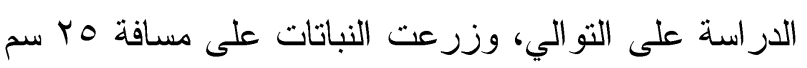

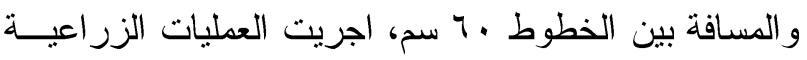
الأخري على حسب توصيات وزارة الزر اعة للمنطقة. وسجلت الصفات التالية (وزن النبــات الغــض و وزن الجذر طول الجذر وقطر الجذر والمحــصول البيولــوجي

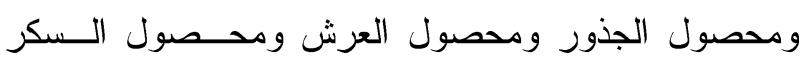
و المو اد الصلبة الذائبة الكلية ونسبة السكروز ومهول أنشارت النتائج المتحصل عليها الي وجــود اختلافــات معنوية بين معاملات الرش الورقي بمنظمات النمو في كل

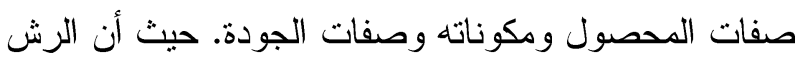

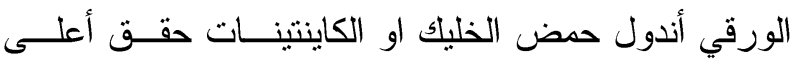

